\title{
IDENTIFIKASI KANDUNGAN ZINK (Zn), BESI (Fe) DAN ESCHERICHIA COLI PADA SUMBER AIR BERSIH DENGAN ANALISIS SPASIAL ECOLOGICAL RISK ASSESMENT DI DESA TUNGKA KECAMATAN ENREKANG KABUPATEN ENREKANG
}

\begin{abstract}
Dirman Sudarman, Alfina Baharuddin, Muhammad Ikhtiar, Haeruddin, Reza Aril Ahri, Sitti Fatimah
\end{abstract}

Program Pascasarjana Kesehatan Masyarakat, Universitas Muslim Indonesia

*Email: dirmansudarman26@gmail.com

\begin{abstract}
ABSTRAK
Latar belakang: Berdasarkan data WHO, diketahui bahwa hampir $40 \%$ penyakit mematikan di seluruh negara berkaitan dengan buruknya kualitas air, ada sekitar 2,6 juta orang diseluruh dunia meninggal setiap tahunnya akibat penyakit yang disebabkan oleh air kotor atau air yang tidak memenuhi syarat kesehatan. Zink dan Besi merupakan zat mineral esensial yang diperlukan oleh tubuh, namun dalam jumlah yang berlebihan akan menyebabkan keracunan. Defisiensi ini menyebabkan gangguan pertumbuhan, mempengaruhi pematangan seksual, mudah terkena infeksi, diare, dan setiap tahunnya menyebabkan kematian sekitar 800.000 anak-anak diseluruh dunia. Penyebab diare terbanyak kedua setelah rotavirus adalah infeksi karena bakteri Escherichia coli angka kejadian diare pada anak tiap tahun diperkirakan 2,5 milyar, dan lebih dari setengahnya terdapat di Afrika dan Asia Selatan dan akibat dari penyakit ini lebih berat serta mematikan. Secara global setiap tahun penyakit ini menyebabkan kematian balita sebesar 1,6 juta.Tujuan: Tujuan penelitian ini adalah untuk mengidentifikasi memetakan Kandungan Zink (Zn), Besi (Fe) Dan Escherichia Coli Pada Sumber Air Bersih dengan Analisis Spasial Ecological Risk Assesment di Desa Tungka Kecamatan Enrekang Kabupaten Enrekang. Metode: penelitian ini adalah observasional deskriftif, untuk mengidentifikasi dan memetakan kandungan Zink (Zn), Besi (Fe) dan Escherichia Coli pada sumber air bersih di Desa Tungka Kecamatan Enrekang Kabupaten Enrekang dan menghitung penilaian resiko ekologinya. Rancangan penelitian dengan menggunakan pendekatan ecological risk assessment. Pengambilan sampel dilakukan pada 6 titik yang berbeda. Hasil: Hasil yang di dapatkan dalam penelitian ini jumlah kandungan zink masih memenuhi syarat standar baku mutu yaitu $<3$ mg/l standar Permenkes RI
\end{abstract}


No.492/Menkes/Per/IV/2010 untuk kandungan zink yaitu $3 \mathrm{mg} / \mathrm{l}$, dengan indeks resiko ekologi potensial yaitu PERI $=\sum E_{r}^{i}(0,831)<150$ dengan kategori resiko rendah. Untuk kandungan besi masih di bawah standar yaitu $<0.3 \mathrm{mg} / \mathrm{l}$ standar Permenkes RI No.492/Menkes/Per/IV/2010 untuk kandungan besi yaitu $0,3 \mathrm{mg} / \mathrm{l}$, dengan indeks resiko ekologi potensial yaitu $\mathrm{PERI}=\sum E_{r}^{i}(0,1797)<150$ dengan kategori resiko rendah. Sedangkan untuk kandungan escerchia coli tidak memenuhi syarat yaitu $>0 \mathrm{CFU} / \mathrm{ml}$ standar baku mutu yaitu Permenkes RI No.492/Menkes/Per/IV/2010 untuk kandungan E. coli yaitu $0 \mathrm{CFU} / \mathrm{ml}$. Dengan indeks resiko yaitu PERI $=\sum E_{r}^{i}\left(46,7.10^{-6}\right)>1.10^{-6}$ dengan kategori resiko sangat tinggi

Kata Kunci : Zink, Besi, Escerchia coli, Ecological Rissk Assessment.

\section{ABSTRACT}

Background: Based on WHO data, it is known that nearly $40 \%$ of deadly diseases in all countries are related to poor water quality, there are around 2.6 million people worldwide die each year due to diseases caused by dirty water or water that does not meet health requirements. Zinc and Iron are essential mineral substances needed by the body, but in excess amounts will cause poisoning. This deficiency causes growth disorders, affects sexual maturation, susceptibility to infections, diarrhea, and annually causes the death of approximately 800,000 children worldwide. The second most common cause of diarrhea after rotavirus is infection due to the bacteria Escherichia coli, the annual incidence of diarrhea in children is estimated at 2.5 billion, and more than half of it is found in Africa and South Asia and the consequences of this disease are more severe and deadly. Globally every year this disease causes the death of children under five of 1.6 million. Objective: The aim of this study is to identify to map the Zinc ( $\mathrm{Zn})$, Iron (Fe) and Escherichia Coli Content in Clean Water Sources with a Spatial Ecological Risk Assessment Analysis in Tungka Village Enrekang District, Enrekang Regency. Methods: This research is descriptive observational, to identify and map the content of zinc ( $\mathrm{Zn}$ ), iron (Fe) and Escherichia Coli in clean water sources in Tungka Village, Enrekang District, Enrekang Regency and calculate the ecological risk assessment. The research design used an ecological risk assessment approach. Sampling was carried out at 6 different points. Results: The results obtained in this study, the amount of zinc content still met the quality standard requirements, namely $<3 \mathrm{mg} / 1$ of the Republic of Indonesia Minister of Health Regulation No.492 / Menkes / Per / IV / 2010 for zinc content, namely $3 \mathrm{mg} / 1$, with a risk index ecological potential, namely PERI = $\sum \mathrm{E} \__{-}{ }^{\wedge} \mathrm{i}(0.831)<150$ with low risk category. The iron content is still below the standard, namely <0.3 mg / 1, the standard Permenkes RI No.492 / Menkes / Per / IV / 2010 for iron content is $0.3 \mathrm{mg} / 1$, with a potential ecological risk index of PERI $=\sum \mathrm{E}_{-} \mathrm{r}^{\wedge} \mathrm{i}(0.1797)<150$ with low risk category. Meanwhile, the content of escerchia coli does not meet the requirements, namely> $0 \mathrm{CFU} / \mathrm{ml}$ quality standards, namely the Republic of Indonesia Minister of Health Regulation No.492 / Menkes / Per / IV / 2010 for the content of E. coli, namely $0 \mathrm{CFU} / \mathrm{ml}$. With a risk index, namely PERI $=\sum \mathrm{E}_{-} \mathrm{r}^{\wedge} \mathrm{i}(46,7.10-6)>1.10-6$ with a very high risk category

Keywords: Zinc, Iron, Escerchia coli, Ecological Rissk Assessment 


\section{LATAR BELAKANG}

Indikator

keberhasilan

pembangunan nasional yang berkaitan dengan bidang kesehatan tidak terlepas dari generasi yang berkualitas. Upaya untuk mewujudkan generasi yang berkualitas yaitu dengan menurunkan angka masalah gizi stunting (pendek). Stunting (pendek) adalah keadaan status gizi yang ditandai dengan tinggi badan anak kurang dari -2 standar deviasi berdasarkan standar World Health Organization (WHO).

Stunting merupakan kondisi kekurangan gizi kronis yang menyebabkan postur tubuh tidak maksimal dan kemampuan kognitif berkurang. Secara global pada tahun 2017 sebanyak $22,2 \%$ atau satu dari empat anak-anak usia 0-5 tahun di dunia mengalami stunting. Prevalensi stunting tertinggi sebesar 35\% ditempati oleh Asia Selatan yang kemudian disusul oleh Afrika Timur dan Selatan sebesar 34,1\% dan Afrika Barat dan Tengah sebesar $33,7 \%{ }^{1}$.

Stunting adalah masalah gizi di dunia, terutama di negara miskin dan berkembang. Mal-gizi masih menjadi masalah kesehatan tertinggi di negara berkembang. Ada 22,2\% kasus stunting di dunia. Pada tahun 2017, lebih dari separuh anak stunting berasal dari Asia
(56\%). Persentase tertinggi terjadi di Asia Selatan sebesar 58,7\%). Indonesia merupakan salah satu negara Asia Tenggara dengan prevalensi stunting sebesar $29,6 \%$ (9,8\% bayi sangat pendek dan $19,8 \%$ bayi pendek) ${ }^{2}$.

Berdasarkan data WHO, diketahui bahwa hampir $40 \%$ penyakit mematikan di seluruh negara berkaitan dengan buruknya kualitas air, selain itu WHO juga mencatat bahwa ada sekitar 2,6 juta orang diseluruh dunia meninggal setiap tahunnya akibat penyakit yang disebabkan oleh air kotor atau air yang tidak memenuhi syarat kesehatan ${ }^{3}$.

Diare erat hubungannya dengan keadaan kurang gizi. Setiap episode diare dapat berakibat kekurangan kemampuan menyerap sari makanan, sehingga apabila episodenya berkepanjangan akan berdampak pada peetumbuhan dan kesehatan anak. Penyakit diare sampai saat ini masih merupakan salah satu penyebab utama kesakitan dan kematian. Hampir seluruh daerah geografis dunia dan semua kelompok usia diserang diare tetapi penyakit berat dengan kematian yang tinggi terutama didapatkan pada bayi dan anakanak. Menurut penelitian sebelumnya diare menyebabkan kematian sebesar 15-34 \% dari semua kematian, yaitu kurang lebih 300 kematian per tahun ${ }^{4}$. 
Berdasarkaan Profil Kesehatan

Kecematan Enrekang untuk kasus diare selalu mengalami degradasi jumlah kasus pada tiap tahunnya. Pada tahun 2017 terdapat 734 kasus,Tahun 2018 terdapat 711 kasus, pada tahun 2019 terdapat 834 kasus secara keseluruhan terkhusus di Desa Tungka terdapat 44 kasus 27 di antaranya adalah balita. Dan KLB kasus diare terjadi pada tahun 2016 terjadi di Dusun Tapuan Desa Tungka hanya dalam 1 bulan terjadi 15 kasus bahkan sampai ada yang meninggal dunia. Kasus diare yang merupakan penyakit yang sudah lama di temukan harusnya jumlah kasusnya bisa di tekan dan tidak ada lagi kasus diare di Kabupaten Enrekang dan Indonesia pada umumnya ${ }^{5}$.

Di dunia, diperkirakan 17,3\% populasi mengalami defisiensi asupan zinc, dengan Asia Tenggara, sekitar 22,1 $\%$ populasi mengalami defisiensi asupan zinc. Prevalensi kasus defisiensi zinc lebih banyak pada negaranegara berkembang,Kekurangan asupan zinc mengakibatkan defisiensi sistem imun, pertumbuhan yang terhambat, gangguan neurologis, hypogonandism pada pria, dan munculnya lesi pada kulit. Bayi, terutama yang tidak mendapatkan asi dan baru mengalami penyapuhan, balita dan anak - anak sangat rentan mengalami defisiensi $z i n c^{6}$.
Menurut Permenkes

RI

No.492/Menkes/Per/IV/2010 persyaratan secara fisik, air minum tidak berbau, tidak berasa, tidak bewarna, dan tidak keruh. Persyaratan bakteriologis air minum tidak boleh terdapat bakteri, sedangkan secara kimia air tidak boleh mengandung senyawa kimia beracun dan setiap zat terlarut dalam air memiliki batas tertentu yang diperbolehkan ${ }^{7}$.

Penelitian yang dilakukan di di wilayahKupang Gunung RT 07 RW 07 KelurahanPutat Jaya Kecamatan Sawahan KotaSurabaya dengan hasil pemeriksaan laboratorium dari kelima sampel air sumur terdapat kadar Besi (Fe) yang melebihi standart baku mutu yaitu pada sumur I 4,85 mg/l, sumur II 6,04 mg/l, sumur III 7,15 mg/l, sumur IV 3,90 mg/l, dan sumur V 5,13 mg/1 ${ }^{8}$.

Apabila konsentrasi besi (Fe) dalam air melebihi batas tersebut maka akan menyebabkan gangguan kesehatan, ekonomis maupun teknis. Sedangkan, menurut Peraturan Menteri Kesehatan Republik Indonesia Nomor 492/MENKES/PER/IV/2010 tentang Persyaratan Kualitas Minum, telah menetapkan standar kualitas besi (Fe) kadar maksimum yang diperboleh-kan adalah $0,3 \mathrm{mg} / \mathrm{L}$.

Berdasarkan latarbelakang diatas, maka peneliti tertatik meneliti dengan 
judul "Identifikasi Kandungan Zink (Zn), Besi (Fe) Dan Escherichia Coli Pada Sumber Air Bersih Dengan Analisis

\section{METODE}

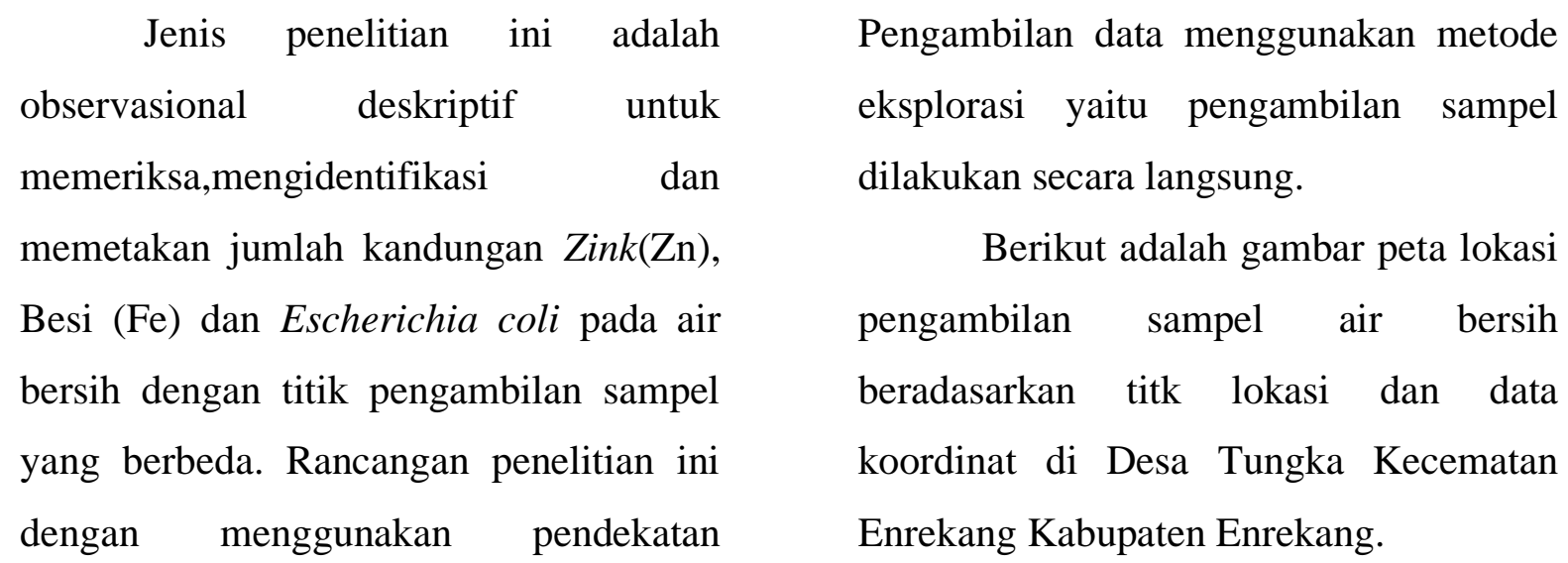

Ecologicaal Risk Assessment (ERA).

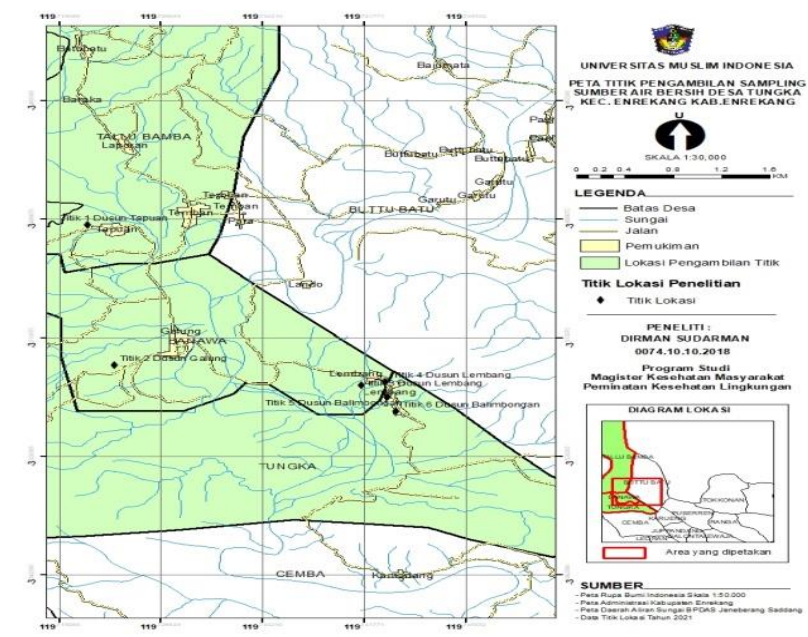

Gambar: 5.1. Peta lokasi pengambilan sampel air bersih di Desa Tungka Kecamatan Enrekang Kabupaten Enrekang.

Titik pengambilan sampel di tentukan berdasarkan kriteria titk sampel. Untuk dusun Tapuan dan dusun Galung pengambilan sampel di ambil berdasarkan sumber air bersih yang ada di dusun tersebut, karna hanya 1 sumber air bersih
Spasial Ecological Risk Assesment Di Desa Tungka Kecamatan Enrekang Kabupaten Enrekang.

\section{Enrekang Kabupaten Enrekang.}


HASIL

\section{Identifikasi Kualitas air secara fisik}

Hasil pengukuran kualitas air

bersih secara Fisik pada setiap titik lokasi sampling dapat di lihat pada tabel 5.2.

sebagai berikut:

Tabel 5.2.

Identifikasi Kualitas Fisik Sumber Air Bersih

Di Desa Tungka Kecamatan Enrekang

Kabupaten Enrekang

\begin{tabular}{ccccccccc}
\hline $\begin{array}{c}\text { Jenis } \\
\text { Parameter }\end{array}$ & \multicolumn{6}{c}{ Lokasi Sampling } & $\begin{array}{c}\text { Standar } \\
\text { Baku Mutu }\end{array}$ & Satuan \\
\cline { 2 - 7 } & $\mathbf{T}_{\mathbf{1}}$ & $\mathbf{T}_{\mathbf{2}}$ & $\mathbf{T}_{\mathbf{3}}$ & $\mathbf{T}_{\mathbf{4}}$ & $\mathbf{T}_{\mathbf{5}}$ & $\mathbf{T}_{\mathbf{6}}$ & \\
Bau & - & - & - & - & - & - & Tidak berbau & \\
Warna & - & - & - & - & - & - & $\begin{array}{c}\text { Tidak } \\
\text { berwarna }\end{array}$ \\
& & & & & & & \\
TDS & 462 & 363 & 987 & 672 & 778 & 978 & 500 & $\mathrm{Mg} / 1$ \\
Kekeruhan & 2 & 2 & 6 & 0 & 4 & 0 & 5 & NTU \\
Rasa & - & - & - & - & - & - & Tidak berasa & \\
Suhu & 28.6 & 29.5 & 30.7 & 30.2 & 30.6 & 29.7 & 3 & $\mathrm{C}$ \\
\hline
\end{tabular}

Sumber: data primer (2021)

Berdasarkan Tabel di atas, dapat kita lihat bahwa identifikasi kualitas sumber air bersih di desa Tungka Kecamatan Enrekang Kabupaten Enrekang untuk parameter bau, warna dan rasa dari $6 \mathrm{~T}$ sampling semua memenuhi syarat. Total zat padat terlarut (TDS) untuk T1 dan T2 yaitu jumlah TDS $\mathrm{T}=462 \mathrm{Mg} / 1, \quad \mathrm{~T} 2=363 \mathrm{Mg} / \mathrm{l}, \quad$ masih di bawah standar baku, sedangkan untuk $\mathrm{T} 3=987, \mathrm{~T} 4=672 \mathrm{Mg} / \mathrm{l}, \mathrm{T} 5=778 \mathrm{Mg} / \mathrm{l}$ dan T6=978 Mg/l jumlah TDS melewati standar baku mutu yaitu $500 \mathrm{mg} / \mathrm{l}$. ParameterkekeruhanT1=2NTU,

$\mathrm{T} 2=2 \mathrm{NTU}, \quad \mathrm{T} 4=0 \mathrm{NTU}, \quad \mathrm{T} 5=5 \mathrm{NTU}$, T6=0NTU, masih memenuhi standar baku mutu dan untuk T3=6NTU, untuk kekeruhannya melewati standar baku mutu yaitu 5 NTU. Sedangkan jenis paramater suhu yaitu $\mathrm{T} 1=28.6^{\circ} \mathrm{C}$, $\mathrm{T} 2=29.5^{\circ} \mathrm{C}, \quad \mathrm{T} 3=30.7^{0} \mathrm{C}, \quad \mathrm{T} 4=30.2^{\circ} \mathrm{C}$, $\mathrm{T} 5=30,6^{\circ} \mathrm{C}$ dan $\mathrm{T} 6=29,7^{\circ} \mathrm{C}$ dari standar baku mutu yang tetah di tetapkan semua titik melebihi ambang batas sesuai dengan standar baku mutu yaitu $3^{0} \mathrm{C}$.

\section{Identifikasi Kandungan $\operatorname{Zink}(Z n)$}

Hasil pengukuran jumlah kandungan zink pada sampel air bersih pada setiap titik lokasi sampling dapat di lihat pada tabel 5.3. berikut: 
Tabel 5.3.

\section{Identifikasi Kandungan Zink(Zn)Pada Sumber Air Bersih} di Desa Tungka Kecamatan Enrekang

Kabupaten Enrekang

\begin{tabular}{ccccc}
\hline Titik sampling & Hasil & $\begin{array}{c}\text { Standar } \\
\text { baku mutu }\end{array}$ & Satuan & $\begin{array}{c}\text { Keterangan } \\
\text { (MS/TMS) }\end{array}$ \\
\hline T1 & 0.020 & & & MS \\
T2 & 0.118 & 3 & $\mathrm{mg} / 1$ & $\mathrm{MS}$ \\
T3 & 0.020 & & & $\mathrm{MS}$ \\
T4 & 0,024 & & $\mathrm{MS}$ \\
T5 & 0,068 & & $\mathrm{MS}$ \\
T6 & 0,027 & & \\
\hline Total & $\mathbf{0 , 2 7 7}$ & & \\
\hline
\end{tabular}

Sumber: data primer (2021)

Berdasarkan tabel 5.3, jumlah kandungan zink pada sumber air bersih di Desa Tungka Kecamatan Enrekang Kabupaten Enrekang setelah di lakukan identifikasi di laboratoriun pada titik $1 \mathrm{di}$ dusun Tapuan dengan jumlah kandungan zink yaitu $0.020 \mathrm{mg} / \mathrm{l}$, titik 2 di dusun Galung yaitu $0.118 \mathrm{mg} / \mathrm{l}$, titik 3 di dusun Lembang1 yaitu $0.020 \mathrm{mgl}$, titik 4 di dusun Lembang2 yaitu $0.024 \mathrm{mg} / \mathrm{l}$, titik 5 di dusun Balimbongan1 yaitu $0.068 \mathrm{mg} / \mathrm{l}$, dan titik 6 di dusun Balimbongan2 yaitu $0.027 \mathrm{mg} / \mathrm{l}$.

Adapun proporsi dari jumlah identifikasi kandungan Zink pada sumber air bersih di desa Tungka Kecamatan Enrekang Kabupaten Enrekang Kecematan Enrekang sebagai berikut:

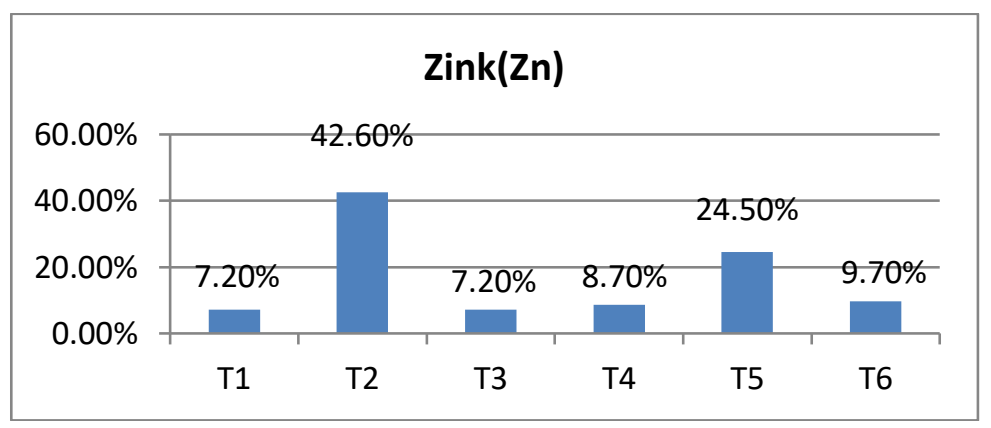

Gambar 5.2. Data proporsi jumlah kandungan zink pada sumber air bersih di desa Tungka Kecamatan Enrekang Kabupaten Enrekang.

Berdasarkan gambar 5.2.di atas dapat kita lihat bahwa di yang mana jumlah kandungan zink paling tinggi dan jumlah kandungan zink paling rendah pada setiap titik berdasarkan gambar di atas.
Proporsi kandungan zink pada sumber air bersih di desa tungka kecamatan enrekang kabupaten enrekang pada $\mathrm{T} 1$ dusun Tapuan yaitu 7,2\%, T2 di dusun Galung yaitu 42,60\%, T3 di dusun Lembang1 yaitu $7,20 \%$, T4 di dusun 
Lembang2 yaitu 8,70\%, T5 di dusun Balimbongan1 yaitu 24,50\%, dan di dusun Balimbongan2 yaitu 9,70\%.
Identifikasi Kandungan Besi(Fe)

Hasil pengukuran jumlah kandungan besi pada sampel air bersih pada setiap titik lokasi sampling dapat di lihat pada Tabel 5.4. berikut:

Tabel 5.4.

Identifikasi Kandungan Besi(Fe) Pada Sumber Air Bersih di Desa Tungka Kecamatan Enrekang

Kabupaten Enrekang

\begin{tabular}{ccccc}
\hline $\begin{array}{c}\text { Titik } \\
\text { sampling }\end{array}$ & Hasil & $\begin{array}{c}\text { Standar } \\
\text { baku mutu }\end{array}$ & Satuan & $\begin{array}{c}\text { Keterangan } \\
\text { (MS/TMS) }\end{array}$ \\
\hline T1 & $<0.033$ & & & MS \\
T2 & $<0.033$ & & $m g / l$ & MS \\
T3 & 0.012 & 0.3 & & MS \\
T4 & 0.124 & & MS \\
T5 & 0.188 & & MS \\
T6 & 0.207 & & MS \\
\hline Total & $\mathbf{0 , 5 9 7}$ & & \\
\hline
\end{tabular}

Sumber: data primer (2021)

Berdasarkan tabel 5.4. jumlah kandunga besi pada sumber air bersih di desa Tungka Kecamatan Enrekang Kabupaten Enrekang setelah di lakukan identifikasi dan pemeriksaan laboratorium pada titik 1 di dusun Tapuan jumlah kandungan besi yaitu $<0.033 \mathrm{mg} / \mathrm{l}$, titik 2 di dusun Galung yaitu $<0.033 \mathrm{mg} / \mathrm{l}$, titik 3 di dususn Lembang1 yaitu $0.012 \mathrm{mg} / \mathrm{l}$, titik 4 di dusun Lembang2 yaitu 0.124 $\mathrm{mg} / \mathrm{l}$, titik 5 di dusun Balimbongan1 yaitu $0.188 \mathrm{mg} / \mathrm{l}$, dan di titik 6 di dusun Balimbongan2 yaitu $0.207 \mathrm{mg} / \mathrm{l}$.

Adapun proporsi dari jumlah identifikasi kandunga besi pada sumber air bersih di desa Tungka Kecamatan Enrekang Kabupaten Enrekang Kecematan Enrekang sebagai berikut:

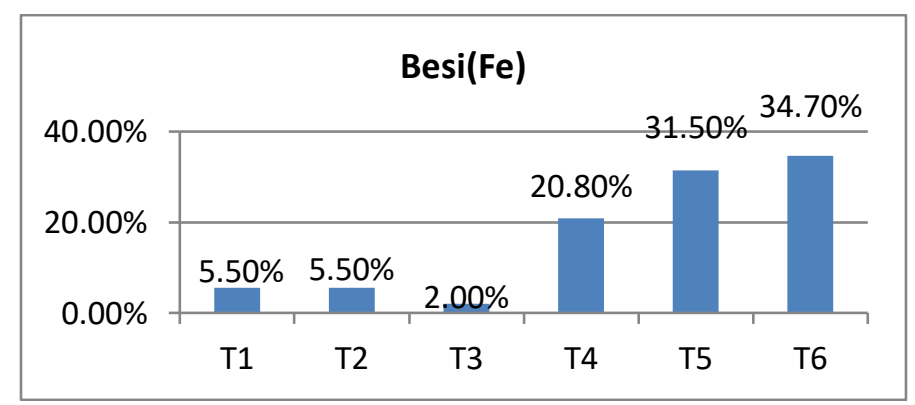

Gambar 5.3. Data proporsi jumlah kandungan besi pada sumber air bersih di desa Tungka Kecamatan Enrekang Kabupaten Enrekang. 
Berdasarkan gambar 5.3.di atas dapat kita lihat bahwa di yang mana jumlah kandungan besi paling tinggi dan jumlah kandungan besi paling rendah pada setiap titik berdasarkan gambar di atas.

Proporsi kandungan besi pada sumber air bersih di desa tungka kecamatan enrekang kabupaten enrekang pada T1 dusun Tapuan yaitu 5,50\%, T2 di dusun Galung yaitu 5,50\%, T3 di dusun
Lembang1 yaitu 2,00\%, T4 di dusun Lembang2 yaitu 20,80\%, T5 di dusun Balimbongan1 yaitu $31,50 \%$, dan di dusun Balimbongan2 yaitu 34,70\%.

\section{Identifikasi Kandungan Ecserchia Coli}

Hasil pengukuran jumlah kandungan Escherichia coli pada sampel air bersih pada setiap titik lokasi sampling dapat di lihat pada tabel 5.5. berikut:

Tabel 5.5.

Identifikasi Kandungan Escherichia ColiPada Sumber Air Bersi DiDesa Tungka Kecamatan Enrekang

Kabupaten Enrekang

\begin{tabular}{|c|c|c|c|c|c|}
\hline $\begin{array}{c}\text { Titik } \\
\text { samping }\end{array}$ & Parameter & Hasil & $\begin{array}{c}\text { Standar baku } \\
\text { mutu }\end{array}$ & Satuan & $\begin{array}{c}\text { Ket. } \\
\text { (MS/TMS) }\end{array}$ \\
\hline \multirow[t]{2}{*}{$\mathrm{T} 1$} & T.1 coliform & 1500 & $50 \mathrm{CFU} / 100 \mathrm{ml}$ & \multirow[b]{2}{*}{$\begin{array}{c}\mathrm{CFU} / 100 \\
\mathrm{ml}\end{array}$} & TMS \\
\hline & E. coli & 55 & 0/CFU/100 ml & & TMS \\
\hline \multirow[t]{2}{*}{$\mathrm{T} 2$} & T. coliform & 6600 & 50CFU/100 ml & \multirow[b]{2}{*}{$\begin{array}{c}\mathrm{CFU} / 100 \\
\mathrm{ml}\end{array}$} & TMS \\
\hline & E. coli & 200 & 0/CFU/100 ml & & TMS \\
\hline \multirow[t]{2}{*}{ T3 } & T. coliform & 6800 & 50CFU/100 ml & \multirow[b]{2}{*}{$\begin{array}{c}\mathrm{CFU} / 100 \\
\mathrm{ml}\end{array}$} & TMS \\
\hline & E. coli & 30 & 0/CFU/100 ml & & TMS \\
\hline \multirow[t]{2}{*}{$\mathrm{T} 4$} & T. coliform & 6800 & $50 \mathrm{CFU} / 100 \mathrm{ml}$ & \multirow[b]{2}{*}{$\begin{array}{c}\mathrm{CFU} / 100 \\
\mathrm{ml}\end{array}$} & TMS \\
\hline & E. coli & 3500 & 0/CFU/100 ml & & TMS \\
\hline \multirow[t]{2}{*}{ T5 } & T. coliform & 19800 & 50CFU/100 ml & \multirow[b]{2}{*}{$\begin{array}{c}\mathrm{CFU} / 100 \\
\mathrm{ml}\end{array}$} & TMS \\
\hline & E. coli & 4700 & 0/CFU/100 ml & & TMS \\
\hline \multirow[t]{2}{*}{ T6 } & T. coliform & 1500 & $50 \mathrm{CFU} / 100 \mathrm{ml}$ & \multirow[b]{2}{*}{$\begin{array}{c}\mathrm{CFU} / 100 \\
\mathrm{ml}\end{array}$} & TMS \\
\hline & E. coli & 100 & 0/CFU/100 ml & & TMS \\
\hline & T. coliform & 43000 & & & \\
\hline Total & E. coli & 8585 & & & \\
\hline
\end{tabular}

Sumber: data primer (2021)

Berdasarkan tabel 5.5, identifikasi kandungan Escherichia coli pada sumber air bersih di desa Tungka Kecamatan Enrekang Kabupaten Enrekang di dusun
Tapuan (T1) sumber air bersih dari mata air hasil uji laboratorium di dapatkan total coliformuntuk uji secara langsung sebanyak $1500 \mathrm{CFU} / 100 \mathrm{ml}$ dan untuk 
Escherichia coli sebanyak 55 CFU/100 $\mathrm{ml}$ dengan pengenceran $10^{2}$. Di dusun Galung(T2) total coliform untuk uji secara langsung sebanyak 6600CFU/100ml, sedangkan untuk Escherichia coli dengan pengenceran $10^{2}$ sebanyak 200 CFU/100ml. Untuk air sumur gali di dusun Lembang1 (T3) total coliform untuk uji secara langsung sebanyak 6800 CFU/100ml, sedangkan untuk Escherichia coli dengan $\begin{array}{llll}\text { pengenceran } & 10^{2} \quad \text { sebanyak } 30\end{array}$ coliform sebanyak $6800 \mathrm{CFU} / 100 \mathrm{ml}$ dan Escherichia coli sebanyak 3500 CFU/100ml dengan pengenceran $10^{2}$. Di dusun Balimbongan1 (T5) dengan pengenceran $10^{2}$ didapatkan total coliform sebanyak 19800 CFU/100ml dan Escherichia coli sebanyak 4700 CFU/100ml. Sedangkan di dusun Balimbongan2 (T6) di dapatkan total coliform sebanyak $1500 \mathrm{CFU} / 100 \mathrm{ml}$ dan Escherichia coli sebanyak 100 CFU/100ml dengan pengenceran $10^{2}$.

CFU/100ml. Dusun Lembang2 (T4) total

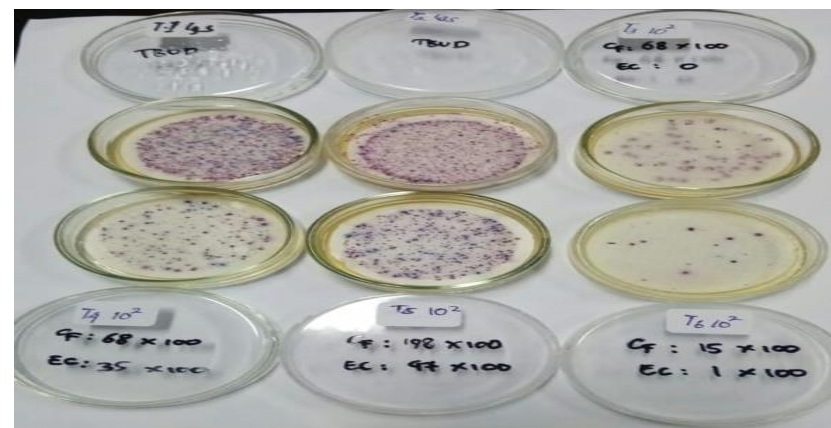

Gambar 5.4 hasil bakteri total coliform danEscherichia colipada media CCA

Gambar 5.4. di atas merupakan bentuk bakteri pada kertas membran di media CCA dari semua titik sumber air bersih Di Desa Tungka Kecamatan Enrekang Kabupaten Enrekang. Pada kertas membran untuk warna pink adalah bakteri total coliform sedangkan warna kebiruan adalah Escherichia coli.
Adapun proporsi dari jumlah identifikasi kandungan Escherichia coli pada sumber air bersih di desa Tungka Kecamatan Enrekang Kabupaten Enrekang Kecematan Enrekang sebagai berikut: 


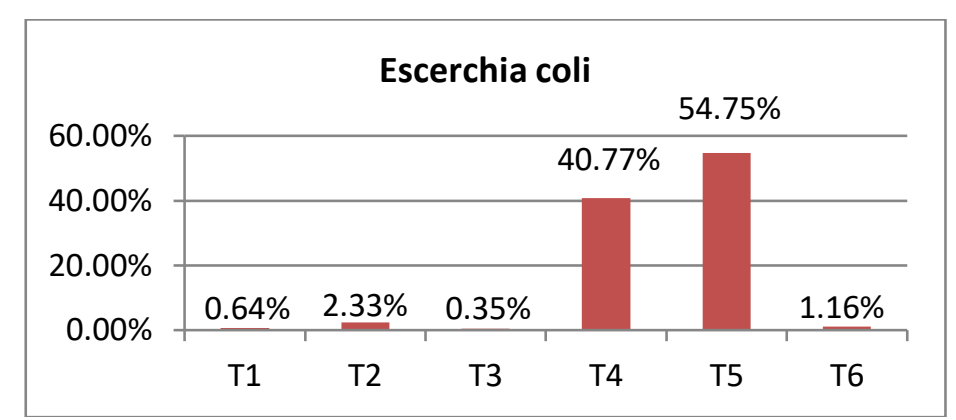

Gambar 5.5. Data proporsi dari jumlah identifikasi kandungan Escherichia coli pada sumber air bersih di Desa Tungka Kecamatan Enrekang Kabupaten EnrekangKecematan Enrekang.

Berdasarkan gambar 5.5 di atas, proporsi jumlah identifikasi kandungan kandungan Escherichia coli pada sumber air bersih di desa Tungka Kecamatan Enrekang Kabupaten Enrekang Kecamatan Enrekangpada T1 dusun Tapuan yaitu $0,64 \%$, T2 di dusun Galung yaitu 2,33\%, T3 di dusun Lembang1 yaitu 0,35\%, T4 di dusun Lembang2 yaitu 40,77\%, T5 di dusun Balimbongan1 yaitu $54,75 \%$, dan di dusun Balimbongan2 yaitu $1,16 \%$.
Ecological Risk Assessment Kandungan Zink(Zn), Besi(Fe) Dan Eceserchia Coli

Ecological Risk Assessment Kandungan $\operatorname{Zink}(\mathrm{Zn})$

Berdasarkan analisis Ecological Risk Assessment kandungan Zink pada sumber air bersih di desa Tungka Kecamatan Enrekang Kabupaten Enrekang dapat di lihat pada Tabel 5.6. sebagai berikut:

Tabel 5.6.

Ecological Risk Assessment Kandungan Zink(Zn) Pada Sumber Air Bersih di Desa Tungka Kecamatan Enrekang

Kabupaten Enrekang

\begin{tabular}{ccc}
\hline Titik sampling & $\boldsymbol{E}_{\boldsymbol{r}}^{\boldsymbol{i}}$ & KategoriResiko \\
\hline T1 & 0,0066 & Resiko rendah \\
T2 & 0,039 & Resiko rendah \\
T3 & 0,0066 & Resiko rendah \\
T4 & 0,008 & Resiko rendah \\
T5 & 0,023 & Resiko rendah \\
T6 & 0,009 & Resiko rendah \\
\hline
\end{tabular}

Sumber: data primer (2021

Berdasarkan Tabel 5.6. Faktor Kontaminasi kandungan zink pada sumber air bersih di desa Tungka Kecamatan Enrekang Kabupaten Enrekang pada titik
1 di dusun Tapuan yaitu 0,0066 dengan resiko rendah, titik 2 di dusun Galung yaitu 0,039 dengan resiko rendah, titik 3 di dusun Lembang1 yaitu 0,0066 dengan 
resiko rendah, titik 4 di dusun Lembang2 yaitu 0,008 dengan resiko rendah, titik 5 di dusun Balimbongan1 yaitu 0,023 dengan resiko rendah, dan titik 6 di dusun Balimbongan2 yaitu 0,009 dengan resiko rendah. Indeks resiko potensial untuk kandungan Zink semua titik lokasi sampling pada sumber air bersih di desa Tungka Kecamatan Enrekang Kabupaten Enrekang di bawah standar faktor indeks resiko potensial dengan kategori resiko rendah yaitu $<40$.

Adapun Indeks Resiko Ekologi Potensial (PERI) kandungan zink dari semua titik lokasi sampling pada sumber air bersih di desa Tungka Kecamatan Enrekang Kabupaten Enrekang yaitu 0,0922 dengan indeks resiko potensial $\mathrm{PERI}=\sum E_{r}^{i}<150$ dengan kategori resiko rendah.

\section{Ecological Risk Assessment Kandungan}

\section{Besi}

Berdasarkan analisis Ecological Risk Assessment kandungan Besi pada sumber air bersih di desa Tungka Kecamatan Enrekang Kabupaten Enrekang dapat di lihat pada tabel 5.7. sebagai berikut:

Tabel 5.7.

Ecological Risk Assessment Kandungan BesiPada Sumber Air Bersih Di Desa Tungka Kecamatan Enrekang Kabupaten Enrekang

\begin{tabular}{ccc}
\hline Titik Sampling & $\boldsymbol{E}_{\boldsymbol{r}}^{\boldsymbol{i}}$ & Kategori Resiko \\
\hline T1 & 0,011 & Resiko rendah \\
T2 & 0,011 & Resiko rendah \\
T3 & 0,040 & Resiko rendah \\
T4 & 0,410 & Resiko rendah \\
T5 & 0,627 & Resiko rendah \\
T6 & 0,687 & Resiko rendah \\
\hline
\end{tabular}

Sumber: data primer(2021)

Berdasarkan tabel 5.7. di atas, indeks resiko potensiali kandungan Besi pada sumber air bersih di desa Tungka Kecamatan Enrekang Kabupaten Enrekang pada titik 1 di dusun Tapuan yaitu 0,011 dengan resiko rendah, titik 2 di dusun Galung yaitu 0,011 dengan resiko rendah, titik 3 di dusun Lembang1 yaitu 0,040 dengan resiko rendah, titik 4 di dusun Lembang2 yaitu 0,410 dengan resiko rendah, titik 5 di dusun Balimbongan1 yaitu 0,627 dengan resiko rendah, dan titik 6 di dusun Balimbongan2 yaitu 0,687 dengan resiko rendah. Indeks resiko potensial untuk kandungan Besi semua titik lokasi sampling pada sumber air bersih di desa Tungka Kecamatan Enrekang Kabupaten 
Enrekang di bawah standar faktor indeks resiko potensial dengan kategori resiko rendah yaitu $<40$.

Adapun Indeks Resiko Potensial (PERI) kandungan Besi dari semua titik lokasi sampling pada sumber air bersih di desa Tungka Kecamatan Enrekang Kabupaten Enrekang yaitu 1,786 dengan indeks resiko potensial PERI $=\sum E_{r}^{i}<150$ dengan kategori resiko rendah.
Ecological Risk Assessment Kandungan Eceserchia Coli

Berdasarkan analisis Ecological Risk Assessment kandungan Ecserchia coli pada sumber air bersih di desa Tungka Kecamatan Enrekang Kabupaten Enrekangdapat di lihat pada Tabel 5.9. sebagai berikut:

Tabel 5.8.

Ecological Risk Assessment Kandungan Eceserchia Coli Pada Sumber Air Bersih Di Desa Tungka Kecamatan Enrekang Kabupaten Enrekang

\begin{tabular}{ccc}
\hline Titik sampling & $\boldsymbol{E}_{\boldsymbol{r}}^{\boldsymbol{i}}$ & $\begin{array}{c}\text { Kategori } \\
\text { Resiko }\end{array}$ \\
\hline T1 & $55.10^{-6}$ & Resiko sangat tinggi \\
T2 & $200.10^{-6}$ & Resiko sangat tinggi \\
T3 & $30.10^{-6}$ & Resiko sangat tinggi \\
T4 & $3500.10^{-6}$ & Resiko sangat tinggi \\
T5 & $4700.10^{-6}$ & Resiko sangat tinggi \\
T6 & $100.10^{-6}$ & Resiko sangat tinggi \\
\hline
\end{tabular}

Sumber: data primer(2021)

Berdasarkan Tabel 5.8. indeks resiko potensial kandungan Escerchia coli pada sumber air bersih di desa Tungka Kecamatan Enrekang Kabupaten Enrekang pada titik 1 di dusun Tapuan yaitu $55.10^{-6}$ dengan resiko sangat tinggi, titik 2 di dusun Galung yaitu 200.10-6 dengan resikoi sangat tinggi, titik 3 di dusun Lembang1 yaitu $30.10^{-6}$ dengan resiko sangat tinggi, titik4 di dusun Lembang2 yaitu $3500.10^{-6}$ dengan resiko sangat tinggi, titik 5 di dusun Balimbongan1 yaitu $4700.10^{-6}$ dengan resiko sangat tinggi, dan titik 6 di dusun Balimbongan2 yaitu $100.10^{-6}$ dengan resiko sangat tinggi. Indeks resiko potensial untuk kandungan Escerchia coli semua titik lokasi sampling pada sumber air bersih di desa Tungka Kecamatan Enrekang Kabupaten Enrekang di atas standar indeks resiko potensial dengan kategori resiko sangat tinggi yaitu $>1.10^{-}$ 6.

Adapun Indeks Resiko Potensial (PERI) kandungan Escerchia coli dari semua titik lokasi sampling pada sumber 
air bersih yang ada di desa Tungka Kecamatan Enrekang Kabupaten Enrekang yaitu 46,7.10 ${ }^{-6}$ dengan indeks resiko potensial kategori resiko sangat tinggi PERI $=\sum E_{r}^{i} \geq 1.10^{-6}$.

\section{PEMBAHASAN}

\section{Identifikas Kandungan Zink}

Berdasarkan penelitian Jumlah kandungan zink yang paling rendah dari 6 titik sumber air bersih yaitu ada pada T1 dusun Tapuan dan T3 dusun Lembang1 dengan kandungan zink yang sama yaitu 0,020 mg/l dengan proporsi 7,20\%. Dan sumber air yang paling tinggi kandungan zink ada pada T2 dusun Galung dengan jumlah kandungan zink yaitu $0,118 \mathrm{mg} / \mathrm{l}$ dengan proporsi yaitu $42,60 \%$. Tingginya kandungan zink pada T2 bukan berarti melewati ambang batas dari standar baku mutu. Standar baku mutu untuk kandungan zink yaitu $3 \mathrm{mg} / \mathrm{l}$. untuk lebih jelasnya dapat kita lihat pada Gambar.5.2.

Artinya bahwa jumlah kandungan zink pada sumber air bersih di Desa Tungka Kecamatan Enrekang Kabupaten Enrekang pada setiap titik masih di bawah standar baku mutu Pada Peraturan Mentri Kesehatan Republik Indonesia Nomor 492/Menkes/Per/IV/2010 Tentang Kualitas Air Minum Parameter Kimiawi jenis parameter Seng/ Zink yaitu $3 \mathrm{Mg} / \mathrm{l}$.
Dari jumlah kandungan zink yang bervariasi pada setiap sumber air bersih itu bisa di sebabkan dari jenis sumber air yang berbeda dan tidak menutup kemungkinan ada hubungannya dengan kandungan unsur tanah dan ekosistem alam di sekitar sumber air bersih.

Asupan zink yang kurang dapat menyebabkan defisiensi zink yang mana dapat menyebabkan alopecia, diare, luka pada kulit, kelainan pada indra pengecap, kehilangan nafsu makan, fungsi imun yang lemah dan perubahan neuropsychiatric. Defisiensi zink pada balita bekaitan dengan menurunnya nafsu makan dan mengakibatkan pola makan yang buruk serta mengakibatkan kegagalan pertumbuhan pada balita. Zink dibutuhkan untuk proses pertumbuhan bukan hanya karena efek replikasi sel dan metabolisme namun juga sebagai mediator hormon pertumbuhan 9 .

\section{Identifikasi Kandungan Besi}

Berdasarkan hasil penelitian jumlah kandungan Besi pada sumber air bersih di desa Tungka Kecamatan Enrekang Kabupaten Enrekang setelah di lakukan identifikasi dan pemeriksaan laboratorium pada titik T1, T1, T3 jumlah kandungan besi masih jauh di ambang batas sedangkan T4, T5, T6 jumlah kandungan besi pada sumber air 
bersih cukup tinggi tetapi belum mencapai pada ambang batas. Artinya bahwa jumlah kandungan besi pada sumber air bersih di Desa Tungka Kecamatan Enrekang Kabupaten Enrekang pada semua titik masih di bawah standar baku mutu Pada Peraturan Mentri Kesehatan Republik Indonesia Nomor 492/ Menkes/Per/IV/2010 Tentang Kualitas Air Minum Parameter Kimiawi jenis parameter Besi $(\mathrm{Fe})$ yaitu $0,3 \mathrm{Mg} / \mathrm{l}$.

Kandungan besi pada sumber air bersih di desa tungka kecamatan enrekang kabupaten enrekang ada pada T6 dusun balimbongan2 dengan jumlah kandungan besi yaitu $0,207 \mathrm{mg} / \mathrm{l}$ dengan proporsi $34,70 \%$ dari 6 titik sumber air besih di desa tungka. Tingginya kandungan besi pada T6 karna dari segi bangunan dan lokasi sumber air bersih yang tidak terawat. Namun dari tingginya kandungan besi tetapi belum melewati ambang batas dari standar baku mutu persyaratan yaitu $0,3 \mathrm{mg} / \mathrm{l}$

Yang menjadi sumber pencemaran besi pada sumber air bersih juga berasal dari mesin bor yang digunakan untuk mengambil air dari sumur yang di simpan di atas di atas bibir sumur dari setiap sumber air bersih ada sekitar 10-15 mesin bor bahkan ada yang sampa 30 mesin bor dalam 1 sumur. Hal ini yang dapat mempengaruhi jumlah kandungan besi pada setiap sumber air bersih.

Berbeda penelitian dengan judul Penentuan Kadar Besi (Fe), Timbal ( $\mathrm{Pb})$, dan Seng (Zn), Pada Air Sumur di Kawasan Binjai Utara dengan Metode Spektofotometri Serapan Atom (SSA) di Laboratorium Kesehatan Daerah, dengan hasil analisis untuk parameter besi yaitu pada sampel air sumur I : 1,924 mg/l, pada sampel air sumur II : 1,858 mg/l, pada air sumur III : 0,759 mg/l.Berdasarkan hasil pemeriksaan tersebut dapat disimpulkan bahwa air minum air bersih untuk parameter Besi telah melewati standar baku mutu kualitas air bersih menurut PERMENKES No.492 Tahun 2010.

Defisiensi zat besi merupakan defisiensi mikronutrien yang paling banyak terjadi di dunia dan dapat menyebabkan pertumbuhan dan perkembangan yang lambat dan penurunan pada perkembangan kognitif ${ }^{10}$. 


\section{Identifikasi Kandungan Ecserchiia Coli}

Berdasarkan hasil pemeriksaan tersebut dapat di simpulkan bahwa semua titik sumber air bersih desa Tungka Kecamatan Enrekang Kabupaten Enrekang untuk kandungan Ecserchia coli sangat tinggi dan melewati standar baku mutu PERMENKES / NO. 492 / IV / 2010 tentang persyaratan kualitas air bersih untuk parameter Mikrobiologi jenis Ecserchia coli yaitu $0 \mathrm{CFU} / \mathrm{ml}$.

Kelimpahan mikrobiologi baik total coliform dan Escerchia coli pada sumber air bersih yang ada di desa Tungka Kecamatan Enrekang Kabupaten Enrekang khususnya pada sumber air dari sumur gali dari hasil pengamatan observasi di sebabkan karna jarak antara sumur gali dengan saluran pembuangan air limbah itu sangat dekat. Pada sumber air di titik T4, T5 dan T6 jarak sumur gali dengan saluran pembuangan air limbah \pm 2 meter, hal ini menyebabkan tingginya total coliform dan Escerhia coli pada kandungan sumber air bersih karna resapan dari saluran pembuangan air limbah masuk ke dalam sumur masuk mencemari kualitas air.

Sejalan dengan penelitiaan dengan judul Kandungan Ecserchia coli Pada Air Sumur Gali Dan Jarak Sumur Dengan Septic Tank Di Kelurahan RapRap Kabupaten Minahasa Utara Tahun
2018, dengan hasil pemerikksaan laboratorium di ketahui jumlah kandungan E. Coli ada pada kisaran 23 sampai dengan >1600 MPN/ml ${ }^{11}$.

\section{Ecological Risk Assessment Kandungan Zink, Besi Dan Ecserchia coli}

Ecological Risk Assessment Kandungan Zink(Zn)

Berdasarkan hasil analisis Ecological Risk Assessment kandungan Zink pada sumber air bersih di desa Tungka Kecamatan Enrekang Kabupaten Enrekang indeks resiko potensial kandungan zink pada sumber air bersih di desa Tungka Kecamatan Enrekang Kabupaten Enrekang di bawah standar faktor indeks resiko potensial dengan kategori resiko rendah yaitu $<40$.Adapun Indeks Resiko Ekologi Potensial (PERI) kandungan zink dari semua titik lokasi sampling pada sumber air bersih di desa Tungka Kecamatan Enrekang Kabupaten Enrekang yaitu 0,0922 dengan indeks resiko potensial PERI $=\sum E_{r}^{i}<150$ dengan kategori resiko rendah.

Kandungan zink dari setiap sumber air tidak melewati ambang batas dengan kategori resiko rendah resiko rendah, namun jika kandugan zink yang kurang juga akan berdampak buruk untuk 
kesehatan dan pertumbuhan, namun tidak dapat di tentukan indeks resiko ekologi potensialnya karna nilai ambang minimum untuk kandungan zink belum ada ketetapannya.Penilaian resiko rendah pada sumber air bersih di desa tungka kecamatan enrekang kabupaten enrekang di sebabkan karna secara alamiah dari segi peridustrian yang berpotensi untuk mencemari ekosistem air bisa di kendalikan, berbeda misalnya pencemaran yang disebabkan oleh pengaruh alam seperti kontruksi dan kandungan tanah yang sebelumnya telah tercemar.Namun yang perlu di perhatikan nilai $E_{r}^{i}$ dari semua titik sumber air bersih yang ada di desa tungka kecamatan enrekang kabupaten enrekang yang sangat jauh di bawah standar baku mutu akan beresiko sebaliknya karna kekurangan kandungan zink.

Penelitian menunjukkan bahwa di daerah dengan aktivitas industri dan perkotaan yang tinggi, konsentrasi polutan yang tinggi selalu terlihat di sedimen dan air permukaan, yang mengancam organisme hidup. Logam berat mengalir ke ekosistem perairan secara langsung melalui pembuangan atau tidak langsung oleh limpasan hujan, dan juga oleh atmosfer. Efek industri dan perkotaan bahan bakar dan limbah, limpasan pertanian, dan kegiatan pertambangan adalah di antara sumber utama masuk langsung aliran logam berat ke dalam ekosistem perairan ${ }^{12}$.

\section{Ecological Risk Assessment Kandungan} Besi

Berdasarkan hasil analisis Ecological Risk Assessment kandungan Besi pada sumber air bersih di desa Tungka Kecamatan Enrekang Kabupaten Enrekang indeks resiko potensial kandungan Besi pada sumber air bersih di desa Tungka Kecamatan Enrekang Kabupaten Enrekang di bawah standar faktor indeks resiko potensial dengan kategori resiko rendah yaitu < 40.Adapun Indeks Resiko Potensial kandungan Besi dari semua titik lokasi sampling pada sumber air bersih di desa Tungka Kecamatan Enrekang Kabupaten Enrekang yaitu 1,786 dengan Indeks Resiko Ekologi Potensial PERI $=\sum E_{r}^{i}<$ 150 dengan kategori resiko rendah.

Air sumur merupakan salah satu sumber air yang sering digunakan masyarakat untuk memenuhi kebutuhan air bersih. Sumber air yang letaknya dekat dengan tempat pembuangan limbah, seperti limbah pabrik atau selokan yang mengandung banyak logam berat, bakteri, virus ataupun parasit membuat air menjadi tercemar. Besi merupakan logam yang banyak mencemari air, dan dapat 
menyebabkan penyakit jika kita terlalu banyak mengonsumsi air tersebut.

Telah ditemukan bahwa sebagian besar logam berat dalam sistem akuatik terkait dengan materi partikulat tersuspensi dan sedimen, sementara logam terlarut teradsorpsi ke partikel halus dan terbawa ke sedimen dasar. Oleh karena itu, sedimen bertindak sebagai penyerap potensial dan merupakan pembawa kontaminan di lingkungan akuatik, karena beberapa polutan dapat didaur ulang melalui perubahan kondisi lingkungan danproses biologis di dalam kolom air. Logam berat yangterakumulasi dalam sedimen dapat dilepaskan ke perairan di atasnya dengan beberapa mekanisme ${ }^{13}$.

Besi (Fe) merupakan mikronutrien yang esensial dalam memproduksi hemoglobin yang berfungsi dalam mengangkut oksigen dari paru-paru ke jaringan tubuh, mengangkut elektron dalam sel, dan dalam mensintesis enzim yang mengandung besi yang dibutuhkan untuk menggunakan oksigen selama memproduksi energi selluler. Defisiensi zat besi merupakan defisiensi mikronutrien yang paling banyak terjadi di dunia dan dapat menyebabkan pertumbuhan dan perkembangan yang lambat dan penurunan pada perkembangan kognitif.
Ecological Risk Assessment Kandungan

\section{Escerchia coli}

Berdasarkan tabel 5.8. di atas, indeks resiko potensial kandungan Escerchia coli pada sumber air bersih di desa Tungka Kecamatan Enrekang Kabupaten Enrekang kandungan E.coli di atas standar indeks resiko potensial dengan kategori resiko sangat kuat yaitu $>1.10^{-6}$.Adapun Indeks Resiko Ekologi Potensial kandungan Escerchia coli dari semua titik lokasi sampling pada sumber air bersih di desa Tungka Kecamatan Enrekang Kabupaten Enrekang yaitu $46,7.10^{-6}$ dengan indeks resiko potensial PERI $=\sum E_{r}^{i} \geq 1.10^{-6}$ dengan kategori resiko sangat tinggi.

Dengan nilai indeks resiko potensial $E_{r}^{i}$ yang sangat tinggi kandungan Escerchia coli pada semua titik suber air bersih yang ada di desa Tungka Kecamatan Enrekang Kabupaten Enrekang menjadi suatu hal yang sangat penting dalam hal penentuan kualitas air bersih. Hal yang menyebabkan menurunnya kualitas air sumur gali yaitu adanya bakteri Escherichia coli. Kandungan Escherichia coli pada air sumur yang dipakai mempunyai peranan besar dalam penularan berbagai penyakit karena apabila air yang sudah tercemar oleh bakteri patogen dan air tersebut digunakan oleh manusia maka dapat 
mengakibatkan gangguan pada kesehatan. Dalam jangka pendek, kualitas air yang tercemar bakteri patogen dapat mengakibatkan muntaber, diare, kolera, tipus, atau disentri ${ }^{14}$.

Risiko kontaminasi mikroba dapat terjadi baik pada suhu normal, dingin maupun panas karena kuman dapat tumbuh pada suhu dingin, biasa atau panas. Dampak kontaminasi mikroba berpotensi menyebabkan diare. Air minum harus memenuhi syarat secara bakteriologis atau kimiawi. Salah satu indikator air minum adalah jumlah bakteri yang ada.Semakin tinggi tingkat kontaminasi bakteri coliform, semakin tinggi pula resiko kehadiran bakteribakteri patogen lain yang biasa hidup dalam kotoran manusia dan hewan. Salah satu contoh bakteri patogen yang kemungkinan terdapat dalam air terkontaminasi kotoran manusia atau hewan berdarah panas ialah bakteri Escherichia coli, yaitu mikroba penyebab gejala diare, demam, kram perut, dan muntah- muntah.

Distribusi SpasialEcological Risk Assessment Kandungan $\operatorname{Zink}(\mathrm{Zn})$, Besi(Fe) dan Ecserchia coli
Distribusi Spasial Ecological Risk Assessment Kandugan Zink (Zn)

Distribusi spasial sistem informasi geografis digunakan untuk mempelajari distribusi spasial logam berat, menganalisis sumber logam dan juga digunakan untuk mempelajaripotensi sumber polusi alami atau buatan manusia $^{15}$.

Secara umum, dalam lingkungan yang tidak terpengaruh, sebagian besar logam berat berada dalam konsentrasi yang sangat rendah, dan pelapukan geologi alami batuan dan tanah, yang secara langsung terpapar ke permukaan air,Logam berat yang dibuang ke sistem perairan oleh sumber alam atau antropogenik selama pengangkutannya didistribusikan antara fase air dan sedimen. Meskipun logam berat bersifat tahan api melalui proses alami di lingkungan, logam berat dapat diubah secara kimiawi oleh organisme dan diubah menjadi kompleks organik, beberapa di antaranya mungkin lebih berbahaya bagi hewan dan kehidupan manusia.

Distribusi ecological risk assessment kandungan zink pada sumber air bersih di Desa Tungka Kecamatan Enrekang Kabupaten Enrekang dapat di lihat pada gambar 5.7. sebagai berikut: 


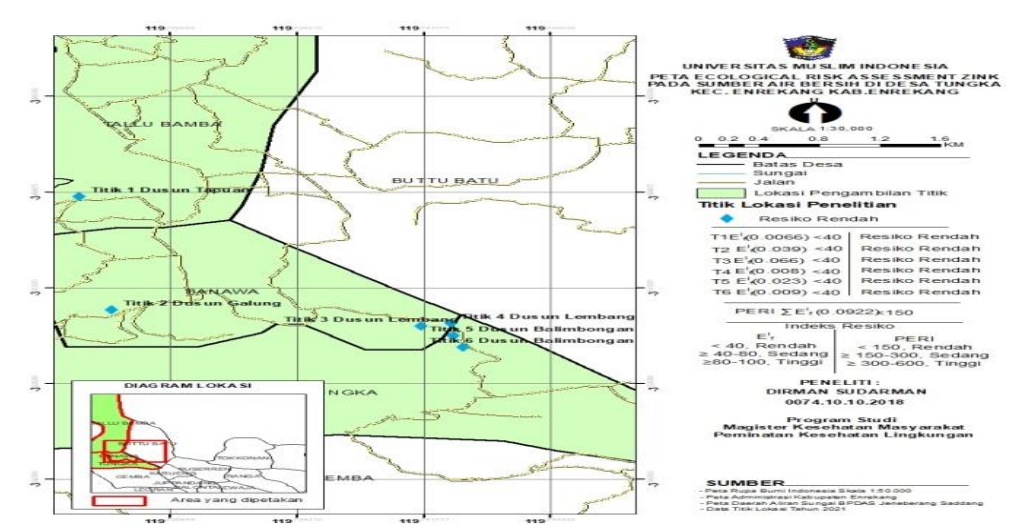

Gambar. 5. 7. Distribusiecological risk assessment kandungan zink pada sumber air bersih di Desa Tungka Kecamatan Enrekang Kabupaten Enrekang.

Distribusi sebaran penilaian resiko ekologi kandungan zink pada sumber air bersih di desa tungka kecamatan Enrekang kabupaten enrekang dari 6 titk lokasi sampling masih dalam kategori rendah di tandai dengan titik warna biru pada peta spasial, hal ini di sebabkan karna jumlah identifikasi kandungan zink pada setiap titik sampling masih di bawah ambang batas.

Penggunaan $\mathrm{Zn}$ terus menerus dengan pertambahan penduduk yang stabil dan kelangkaan lahan yang relatif langka, budidaya pertanian semakin berkembang, termasuk intensi pengolahan tanah dan irigasi, dan peningkatan aplikasi pupuk, pestisida, dan herbisida. Singkatnya, berbagai aktivitas antropogenik mengakibatkan penumpukan $\mathrm{Zn}$ dan bahan logam lainnya menyebabkan konsentrasi logam berat di permukaan melebihi nilai latar.

Perbandingan penilaian PER mencapai kesimpulan yang sama $\mathrm{Zn}$ kemungkinan besar menyebabkan tingkat risiko ekologi yang rendah, Menurut tingkat risiko ekologi dari satu logam, risiko ekologi yang terkait dengan $\mathrm{Zn}$ umumnya rendah.Hal ini dapat dikaitkan dengan faktor respons toksik yang tinggi dan tingkat kontaminasi di danau-danau ini.

Distribusi Spasial Ecological Risk Assessment Kandugan Besi (Fe)

Dengan pesatnya perkembangan industri dan pertanian, pencemaran logam berat saat ini menjadi faktor penting yang mengancam kesehatan ekosistem regional, dan menjadi pusat penelitian umum di bidang geografi, ilmu lingkungan dan ilmu kelautan. Di lautan, ketika unsur-unsur logam berat dibuang ke lingkungan perairan ${ }^{16}$.

Distribusi ecological risk assessment kandungan besi pada sumber air bersih di Desa Tungka Kecamatan 
Enrekang Kabupaten Enrekang dapat di lihat pada gambar 5.8. sebagai berikut:

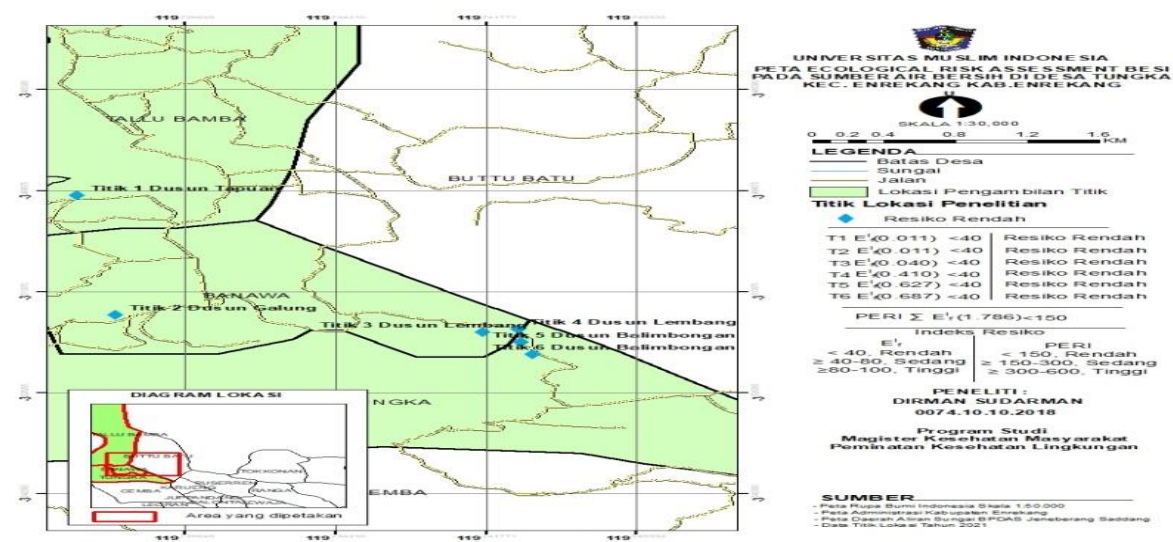

Gambar. 5. 8. Distribusiecological risk assessment kandungan Besi pada sumber air bersih di Desa Tungka Kecamatan Enrekang Kabupaten Enrekang.

Distribusi ecological risk mengingat dampakyang dapat assessment kandungan besi pada sumber air bersih di Desa Tungka Kecamatan Enrekang Kabupaten Enrekang pada semua titik sampling sumber air bersih masih memenuhi syarat dengan kategori resiko rendahdi tandai dengan warna biru pada titik lokasi sampling pada peta spasial. Artiya bahwa sebaran kandungan besi pada sumber air bersih masih bisa di tolerir, tetapi tidak menutup kemungkinan kandungan besi akan meningkat seiring perkembangan pada bidang pertanian dan industri yang dapat memiicu percemaran kualitas sumber air bersih.

Analisis kandungan logam ini sangat penting untuk dilakukan ditimbulkannya sangat berbahaya bagi kesehatan manusia. Dampak negatif yang dapat ditimbulkan logam besi (Fe) menyebabkan gangguan kesehatan yaitu bersifat toksis terhadap organ melalui gangguan secara fisiologis, misalnya kerusakan dinding usus ${ }^{17}$.

Distribusi Spasial Ecological Risk Assessment Kandugan Escrchia coli

Distribusi ecological risk assessment kandungan escerchia colipada sumber air bersih di Desa Tungka Kecamatan Enrekang Kabupaten Enrekang dapat di lihat pada gambar 5.9. sebagai berikut: 


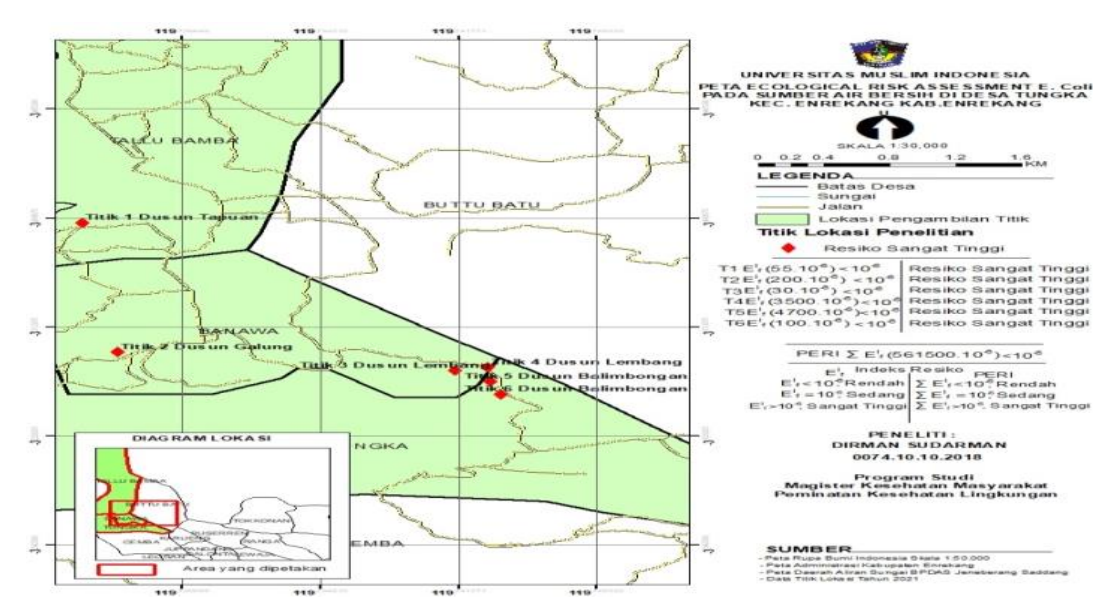

Gambar.5.9.Distribusi ecological risk assessment kandunganescrchia colipada sumber air bersih di Desa Tungka Kecamatan Enrekang Kabupaten Enrekang.

Distribusi ecological risk assessment kandungan escerchiacoli pada sumber air bersih di desa Tungka Kecamatan Enrekang Kabupaten Enrekang dengan kategori resiko sangat sangat tinggi pada semua titik sampling di tandai dengan warna merah pada peta spasial. Hal ini di sebabkan karna kondisi sumber air bersih yang tidak memenuhi syarat. tingginya angka total coliform diakibatkan oleh konstruksi sumur yang tidak memenuhi syarat terlebih jika sumur gali tersebut berdekatan dengan sumber pencemar.

Dari beberapa titik sampling sumber air bersih di desa Tungka Kecamatan Enrekang Kabupaten Enrekang 4 di antaranya menggunakan sumber air bersih dari sumur gali dan tidak memenuhi syarat. Kualitas air bersih dari sumur gali sangat besar potensinya untuk tercemar jika tidak memperhatikan faktor-faktor pencemaran di sekitar sumur.

\section{KESIMPULAN}

Berdasarkan hasil penetilian yang telah dilakukan, maka dapat di di tarik kesimpulan sebagai berikut:

1. Jumlah kandungan zink pada sumber air bersih di desa Tungka Kecamatan Enrekang Kabupaten Enrekang masih di bawah standar yaitu $\mathrm{T} 1$ $(0,020 \mathrm{mg} / \mathrm{l}), \mathrm{T} 2 \quad(0,118 \mathrm{mg} / \mathrm{l}), \quad \mathrm{T} 3$ $(0,020 \mathrm{mg} / \mathrm{l}), \quad \mathrm{T} 4 \quad(0,24 \mathrm{mg} / \mathrm{l}), \quad \mathrm{T} 5$ $(0,068 \mathrm{mg} / \mathrm{l})$, T6 (0,027mg/l). standar baku mutu kesehatan sesuai dengan Permenkes

RINo.492/Menkes/Per/IV/2010 untuk kandungan zink yaitu $3 \mathrm{mg} / \mathrm{l}$.

2. Jumlah kandungan besi pada sumber air bersih di desa Tungka Kecamatan Enrekang Kabupaten Enrekangmasih di bawah standaryaitu T1 $(<0,033 \mathrm{mg} / \mathrm{l}), \mathrm{T} 2 \quad(<0,033 \mathrm{mg} / \mathrm{l}), \quad \mathrm{T} 3$ $(0,012 \mathrm{mg} / \mathrm{l}), \quad \mathrm{T} 4 \quad(0,124 \mathrm{mg} / \mathrm{l}), \quad \mathrm{T} 5$ $(0,188 \mathrm{mg} / \mathrm{l})$, T6 (0,207mg/l). standar kesehatan sesuai dengan Permenkes 
RINo.492/Menkes/Per/IV/2010 untuk kandungan besi yaitu $0,3 \mathrm{mg} / \mathrm{l}$.

3. Jumlah kandungan escerchia coli pada sumber air bersih di desa Tungka Kecamatan Enrekang Kabupaten Enrekang sangat tinggi di atas standar baku mutu yaitu T1 (55 CFU/ml),T2 (200 CFU/ml), T3 (30 CFU/ml), T4 (3500 CFU/ml), T5 (4700 CFU/ml), T6 (100 CFU/ml). standar kesehatan sesuai dengan Permenkes

RINo.492/Menkes/Per/IV/2010 untuk kandungan escerchia coli yaitu 0 $\mathrm{CFU} / \mathrm{ml}$.

4. Ecological riskk asessment sumber air bersih di desa Tungka Kecamatan Enrekang Kabupaten Enrekang kandungan zink dengan indeks resiko ekologi potensial yaitu $\mathrm{PERI}=\sum E_{r}^{i}$ $(0,0922)<150$ dengan kategori resiko rendah, kandungan besi dengan indeks resiko resiko ekologi potensial yaitu $\quad \mathrm{PERI}=\sum E_{r}^{i} \quad(1,786)<150$ dengan kategori resiko rendah, sedangkan kandungan escerchia colidengan indeks resiko potensial yaitu PERI $=\sum E_{r}^{i}\left(46,7.10^{-6}\right)>1.10^{-6}$ dengan kategori resiko sangat tinggi.

5. Distribusi spasial ecological risk assessment kandungan zink, besi dan escerchia coli pada sumber air bersih di desa Tungka Kecamatan Enrekang
Kabupaten Enrekang menunjukan bahwa kandungan zink dan besi masih di bawah standar baku mutu dengan kategori resiko rendah dan di tandai dengan titik warna biru pada peta spasial. Sedangkaan kandungan escerhia coli pada sumber air bersih air bersih melewatii jauh di atas standar baku mutu dengan kategori resiko sangat tinggi dan di tandai dengan titik warna merah pada peta spasial.

\section{SARAN}

1. Bagi masyarakat desa tungka harus memperhatikan cara penggolaan air bersih untuk kegiatan sehari hari mengingat jumlah kandungan bakteri pada sumber air bersih sangat tinggi.

2. Untuk pemerintah desa di harapkan selalu mengawasi masyarakatnya jika ada yang membuat sumber air khusus sumur gali harus di perhatian lokasi dan strategis dalam pembuatan sumur gali tersebut. Mengingat sumur gali yang sudah ada dari segi kontruksi dan bangunan tidak memenuhi persyaratan.

3. Sebagai bahan rujukan pemerintah terkait khususnya Dines Kesehatan Kabupaten Enrekang agar selalu mengontrol dan melakukan pemeriiksaan secara rutin pada 
sumber air bersih di desa Tungka dan melakukan tindak lanjut mengingat jumlah bakteri sumber air bersih tersebut tidk memenuhi persyaratan.

\section{UCAPAN TERIMAH KASIH}

Saya ucapkan terimah kasih yang tak terhingga kepada semua pihak yang sempat terlibat dalam pelaksanaan penelitian ini, khusus bapak/ibu pembimbing dan penguji(Alfina Baharuddin, Muhammad Ikhtiar, Haeruddin, Reza Aril Fahri, Sitti Fatimah) yang telah membantu dan memberi arahan sehingga penelitian ini dapat di laksanakan.

\section{DAFTAR PUSTAKA}

1. UNICEF.2018. Prevalensi Stunting, United Nations Children's Fun

2. Riskesdas, K. (2018). Hasil Utama Riset Kesehata Dasar (RISKESDAS). Journal of Physics A: Mathematical and Theoretical, 44(8), 1-200. https://doi.org/10.1088/1751-

\section{$\underline{8113 / 44 / 8 / 085201}$}

3. WHO. 2019. Standar Deviasi. World Health Organization

4. Riwinarsih, D., Djayusmantoko, D., \& Merita, M. (2020). Hubungan Kebiasaan Konsumsi Makanan Sumber Seng dan Zat Besi serta Kejadian Diare
5. Dinkes Enrekang (2018). Prevalensi Penurunan Stunting. Dines Kesehatan Kabupaten Enrekang

6. Ningsih, L. W. P. (2020). Jurnal medika udayana. Hasil Penelitian Ini Menunjukkan Proporsi Subjek Dengan IMT Berat Badan Rendah Dan Obesitas Cukup Tinggi (20,00\% Dan 16,80\%). Data Utama Yang Dianalisis Yaitu Mengenai Kesesuaian Persepsi Nyata Responden Dengan IMT Subjek. Penelitian Ini Mendapatkan Hasil, 9(1), 22-27.

7. Permenkes No. 492/Th.2010. (2010). Persyaratan Kualitas Air Minum. In Peraturan Mentri Kesehatan Republik Indonesia (Issue 492).

8. Fentz, V. (1962). Hypertensive Encephalopathy in a Child. Acta Neurologica Scandinavica, 38(4), 307-312.

https://doi.org/10.1111/j.1600-

0404.1962.tb01105.x

9. Maharani, D. G., \& Kusumastuti, A. C. (2017). Pengaruh Suplementasi Seng Dan Zat Besi Terhadap Tingkat Kecukupan Energi Balita Usia 3 - 5 Tahun Di Kota Semarang. Journal of Nutrition College, 6(4), 293. https://doi.org/10.14710/jnc.v6i4.1866 $\underline{4}$ 
10. Cindy Annissa Rachmaningrum dan Aryu Candra, Pengaruh Suplementasi Seng (Zn) Dan Zat Besi (Fe) Terhadap Kadar Hemoglobin Balita Usia 3-5 Tahun, Volume 5, Nomor 4, Journal Of Nutrition College.

11. Awuy, Dkk. (2018). Kandungan Escercherichia coli Pada Sumur Gali Dan Jarak Sumur Dengan Septic Tank Di Kelurahan Rap- Rap Kabupaten Minahasa

12. Ghasemi, S., Moghaddam, S. S., Rahimi, A., Damalas, C. A., \& Naji, A. (2018). Ecological risk assessment of coastal ecosystems: The case of mangrove forests in Hormozgan Province, Iran. Chemosphere, 191, 417-426.

https://doi.org/10.1016/j.chemosphere .2017 .10 .047

13. Mohamaden, M. I. I., Khalil, M. K., Draz, S. E. O., \& Hamoda, A. Z. M. (2017). Ecological risk assessment and spatial distribution of some heavy metals in surface sediments of New Valley, Western Desert, Egypt. Egyptian Journal of Aquatic Research, 43(1), 31-43. https://doi.org/10.1016/j.ejar.2016.12. $\underline{001}$

14. Maradesa, S., Lawalata, H. ., \& Tengker, A. (2020). Analisis Kandungan Bakteri Escherichia Coli
Pada Air Sumur Gali Di Kecamatan Lirung Kabupaten Kepulauan Talaud. JSME(Jurnal Sains, Matematika, Dan Edukasi), 8(2), 159-166.

15. Zhang, M., He, P., Qiao, G., Huang, J., Yuan, X., \& Li, Q. (2019). Heavy metal contamination assessment of surface sediments of the Subei Shoal, China: Spatial distribution, source apportionment and ecological risk. Chemosphere, 223, 211-222.

16. Dash, S., Borah, S. S., \& Kalamdhad, A. S. (2021). Heavy metal pollution and potential ecological risk assessment for surficial sediments of Deepor Beel, India. Ecological Indicators, 122(November 2020). https://doi.org/10.1016/j.ecolind.2020. $\underline{107265}$

17. Sriwinarsih, D., Djayusmantoko, D., \& Merita, M. (2020). Hubungan Kebiasaan Konsumsi Makanan Sumber Seng dan Zat Besi serta Kejadian Diare dengan Kejadian Stunting pada Balita Usia 1-3 Tahun di Wilayah Kerja Puskesmas Sungai Jering Kabupaten Merangin. Jurnal Akademika Baiturrahim Jambi, 9(1), 25.https://doi.org/10.36565/jab.v9i1.1 54 